\title{
CONTEXTUAL EFFECT OF HEALTH CENTER AND QUALITY DIMENSIONS OF ANTENATAL SERVICE ON PATIENT SATISFACTION IN KLATEN, CENTRAL JAVA
}

\author{
Leny Rahmawati'), Didik Tamtomo²), Bhisma Murti') \\ 1)Masters Program in Public Health, Universitas Sebelas Maret \\ 2)Faculty of Medicine, Universitas Sebelas Maret
}

\begin{abstract}
Background: Puskesmas plays an important role in reducing maternal and neonatal morbidity and mortality. Contextual factors of health center and dimensions of service quality may influence patients statisfaction. This study aimed to analyze the factors that influence patient satisfaction

Subject and Method: This was an observational study using cross sectional design conducted in Klaten Regency, Central Java. A sample of 200 antenatal patients was selected at random from 25 puskesmas (community health centers) comprising 8 antenatal patients from each selected puskesmas. The dependent variable was antenatal care (ANC) patient satisfaction. The independent variables were five dimensions of quality healthcare, including (1) reliability, (2) tangible, (3) empathy, (4) responsiveness, (5) assurance. The data were analyzed by multilevel linear regression using the Stata 14 application.

Results: Patient satisfaction was positively affected by reliability $(b=0.30 ; 95 \% \mathrm{CI}=-$ 0.48 to $-0.13 ; \mathrm{p}=0.001)$, tangible $(\mathrm{b}=0.28 ; 95 \% \mathrm{CI}=0.14$ to $0.42 ; \mathrm{p}<0.001)$, responsiveness $(b=0.17 ; 95 \% \mathrm{CI}=0.07$ to $0.27 ; \mathrm{p}=0.001)$, and assurance $(\mathrm{b}=0.16 ; 95 \% \mathrm{CI}=$ 0.04 to $0.28 ; \mathrm{p}=0.007)$. The relationship between patient statisfaction and empathy was statistically non significant $(b=-0.02 ; 95 \% \mathrm{CI}=-0.28$ to $0.23 ; \mathrm{p}=0.837)$. The contextual effect at the puskesmas level was substantial with intraclass correlation (ICC= 36.4\%).

Conclusion: Patient satisfaction is positively affected by reliability, tangible, responsiveness, and assurance. The relationship between patient statisfaction and empathy is statistically non significant.
\end{abstract}

Keywords: satisfaction, community health center, quality of health service

\section{Correspondence:}

Leny Rahmawati. Masters Program in Public Health, Universitas Sebelas Maret. Jl. Ir. Sutami 36A, Surakarta 57126, Central Java. Email: lovejesus251200@gmail.com. Mobile: +6288981023493 . 